\title{
Early unusual ozone loss during the Arctic winter 2002/2003 compared to other winters
}

\author{
F. Goutail ${ }^{1}$, J.-P. Pommereau ${ }^{1}$, F. Lefèvre ${ }^{1}$, M. Van Roozendael $^{2}$, S. B. Andersen ${ }^{3}$, B.-A. Kåstad Høiskar ${ }^{4}$, \\ V. Dorokhov ${ }^{5}$, E. Kyrö ${ }^{6}$, M. P. Chipperfield ${ }^{7}$, and W. Feng ${ }^{7}$ \\ ${ }^{1}$ Service d'Aeronomie, CNRS, Verrières le Buisson, France \\ ${ }^{2}$ Belgian Institute for Space Aeronomy (BIRA), Brussels, Belgium \\ ${ }^{3}$ Danish Meteorological Institute, Copenhagen, Denmark \\ ${ }^{4}$ Institute for Air Research, Kjeller, Norway \\ ${ }^{5}$ Central Aerological Observatory, Moscow, Russia \\ ${ }^{6}$ Finnish Meteorological Institute, Sodankylä, Finland \\ ${ }^{7}$ Institute of Atmospheric Science, School of Earth and Environment, University of Leeds, Leeds, UK
}

Received: 27 May 2004 - Published in Atmos. Chem. Phys. Discuss.: 7 September 2004

Revised: 24 January 2005 - Accepted: 18 February 2005 - Published: 2 March 2005

\begin{abstract}
Ozone loss during the winter 2002/2003 has been evaluated from comparisons between total ozone reported by the SAOZ network and simulated in passive mode by both REPROBUS and SLIMCAT. Despite the fact that the two models have a different approach to calculate the descent inside vortex, both evaluations provide similar results $18 \pm 4 \%$ using REPROBUS and $20 \pm 4 \%$ using SLIMCAT and show that the loss started around mid-December, at least ten to twenty days earlier than during any of the previous eleven winters, except 1993/1994. This unusual behaviour is consistent with the low temperatures reported in the stratosphere as well to the signature of early chlorine activation indicated by ground-based, balloon and satellite observations.

A significant ozone loss is also simulated by the current versions of two models, but of lesser amplitude compared to SAOZ, $13 \pm 2 \%$ for REPROBUS and $16 \pm 2 \%$ for SLIMCAT, the underestimation being already observed by mid-January. The early ozone depletion captured by both model show that chemical depletion did indeed take place in December, predominantly at the illuminated edge of the distorted vortex, but the reason for the underestimation compared to the observations and the differences among the models have still to be investigated.
\end{abstract}

\section{Introduction}

Though first signs of stratospheric chemical ozone losses in the Arctic have been reported since 1990 (Hoffman et al., 1989, 1991), the large activity of planetary waves in the northern hemisphere, and thus transport related changes of ozone total column, makes the evaluation of photochemical destruction far more difficult than in the southern hemisphere. To overcome the difficulty, several methods for removing the contribution of transport have been suggested, described and compared by Harris et al. (2002). Among these is the transport model approach used for deriving the chemical ozone reduction from ground based total ozone measurements consisting in comparing the measurements to 3D model simulations in which ozone is considered as a passive tracer (Goutail et al., 1999).

The amplitude of the ozone loss is very sensitive to stratospheric temperature history during the winter. The period of ozone destruction and the cumulative loss are thus highly variable from one winter to another. In general, the analyses using the various methods agree to show that strongest ozone losses are occurring during coldest winters while very little or no destruction could be observed during warmest. However the results are less consistent when the loss starts in the early winter in December-January when the sun is low above the horizon. In that case, not only the various methods disagree (Tilmnes et al., 2004) casting doubt on the existence of early winter destruction, equally difficult to capture by photochemical models (Goutail et al., 1999). 
Table 1. Arctic ground-based SAOZ NDSC stations.

\begin{tabular}{lllll}
\hline Location & Lat. & Long. & Since & Institute \\
\hline Ny-Alesund, Svalbard & $79 \mathrm{~N}$ & $12 \mathrm{E}$ & 1991 & NILU \\
Thule, West Greenland & $77 \mathrm{~N}$ & $69 \mathrm{~W}$ & 1991 & DMI \\
Scoresbysund, Greenld & $70 \mathrm{~N}$ & $22 \mathrm{~W}$ & 1991 & CNRS/DMI \\
Zhigansk, East Siberia & $67 \mathrm{~N}$ & $123 \mathrm{E}$ & 1991 & CNRS/CAO \\
Salekhard, W. Siberia & $67 \mathrm{~N}$ & $67 \mathrm{E}$ & 1998 & CNRS/CAO \\
Sodankyla, Finland & $67 \mathrm{~N}$ & $27 \mathrm{E}$ & 1990 & CNRS/FMI \\
Harestua, Norway & $60 \mathrm{~N}$ & $11 \mathrm{E}$ & 1993 & IASB \\
\hline
\end{tabular}

This paper deals with the ozone loss of the winter 2002/2003, not of particularly dramatic amplitude, but, at least according to SAOZ evaluation, starting exceptionally in early December. This unique event will be used for checking the ability of models using the most recent photochemical rates of Sander et al. (2003) to capture such low sun loss. The paper is organised as follows. First is a short recall of the SAOZ measurements and the 3-D Chemistry-Transport Models (CTM) used. The average ozone loss which could be determined by the technique for the winter 2002/2003 is detailed in Sect. 3. Section 4 provides a summary of relevant PSC (Polar stratospheric Clouds), chlorine activation and ozone loss reports for the same winter supporting those findings. In Sect. 5, the 2002/2003 loss will be compared to that observed during previous years since 1993, showing how exceptional could be the case of 2002/2003. Finally, the ability of the REPROBUS and SLIMCAT 3D CTM models to capture the early ozone destruction of 2002/2003 is investigated and discussed in Sect. 6.

\section{Measurements and models}

The data used here are total ozone columns measured at seven Arctic stations equipped with SAOZ UV-visible spectrometers (Pommereau and Goutail, 1988) part of the Network for the Detection of Stratospheric Changes (NDSC), plus those of a similar spectrometer but of different design operated at Harestua in Southern Norway (Van Roozendael et al., 1995). The location of the stations, the date of installation and the institutes running the instruments are displayed in Table 1. Among those spectrometers, those located at or southward of the Polar Circle are providing data throughout the whole winter, Scoresbysund at $70^{\circ} \mathrm{N}$ starts observing only in mid-January, and Thule and $\mathrm{Ny}$-Alesund around $78^{\circ} \mathrm{N}$ only after mid-February.

Ozone slant columns are measured every morning and evening between $86^{\circ}$ and $91^{\circ}$ solar zenith angle (SZA) in the visible Chappuis bands where the absorption cross-sections are well known (1\% uncertainty) and insensitive to temperature $(<1 \%)$. Total ozone is retrieved from slant column densities using a constant Air Mass Factor (AMF) calcu- lated for a typical winter ozone profile in the vortex measured by the balloon-borne version of the SAOZ instrument from Kiruna in Sweden in 2000. The AMF at $90^{\circ} \mathrm{SZA}$ is 16.5. According to Sarkissian et al. (1995), AMF fluctuations related to changes in ozone profile shape are smaller than 3\%. As demonstrated by several intercomparison campaigns (Vaughan et al., 1997; Roscoe et al., 1999), the measurements of different SAOZ instruments are consistent within $\pm 3 \%$ (about 15 DU). The presence of dense high altitude type II PSCs, which lead to an underestimation of total ozone in the zenith sky measurements because of the lifting of the scattering layer, is detected by a colour index method (Sarkissian et al., 1991). The corresponding ozone data are removed.

The cumulative ozone loss throughout the season is derived following the method described by Goutail et al. (1999) consisting in calculating the difference between total ozone observed and simulated by a CTM (Chemical Transport Model) run in passive mode, that is ignoring chemistry. The models runs are initialised at the beginning of the winter using the ozone distribution provided by ECMWF (European Centre for Medium-Range Weather Forecasts). "Passive ozone" columns are then extracted in coincidence with each SAOZ observation during the course of the winter. The difference between observed and modelled passive ozone columns thus provides an estimate of the photochemical loss.

Two 3-D CTM models have been used in this analysis: REPROBUS (Lefèvre et al., 1994, 1998) and SLIMCAT (Chipperfield, 1999).

REPROBUS calculations are performed on 42 levels extending from the ground up to $0.1 \mathrm{hPa}$ (about $65 \mathrm{~km}$ ) with a $2 \times 2$ degrees horizontal resolution (approximately $220 \mathrm{~km} \times 90 \mathrm{~km}$ at the polar circle) forced by the 6 hourly ECMWF analyses. The vertical transport is derived from ECMWF vertical winds. For the 2002/2003 simulations, the $\mathrm{O}_{3}$ field was initialised from the ECMWF three-dimensional $\mathrm{O}_{3}$ analysis on 1 December 2002.

SLIMCAT simulations are performed with a recent version in which ozone fields are extended down to the troposphere on hybrid $\sigma-\theta$ coordinate (Feng et al., 2005). The model is forced by ECMWF analyses (instead of UKMO United Kingdom Met. Office - previously) and has a horizontal resolution of $2.8^{\circ} \times 2.8^{\circ}$ with 24 levels from the surface to $\sim 55 \mathrm{~km}$. A noticeable difference with REPROBUS is the calculation of vertical advection. SLIMCAT calculates heating rates with a radiation scheme computing solar radiation including code based on NCAR CCM (Briegleb, 1992), whereas REPROBUS uses vertical velocities calculated by ECMWF. As for REPROBUS, the $\mathrm{O}_{3}$ field was initialised on 1 December 2002.

The present study is limited to the polar stratospheric vortex. The selection of the data is based on potential vorticity (PV) fields calculated at $475 \mathrm{~K}$ by the Danish Meteorological Institute from ECMWF analyses. The boundary of the vortex is defined by the maximum PV gradient following the 


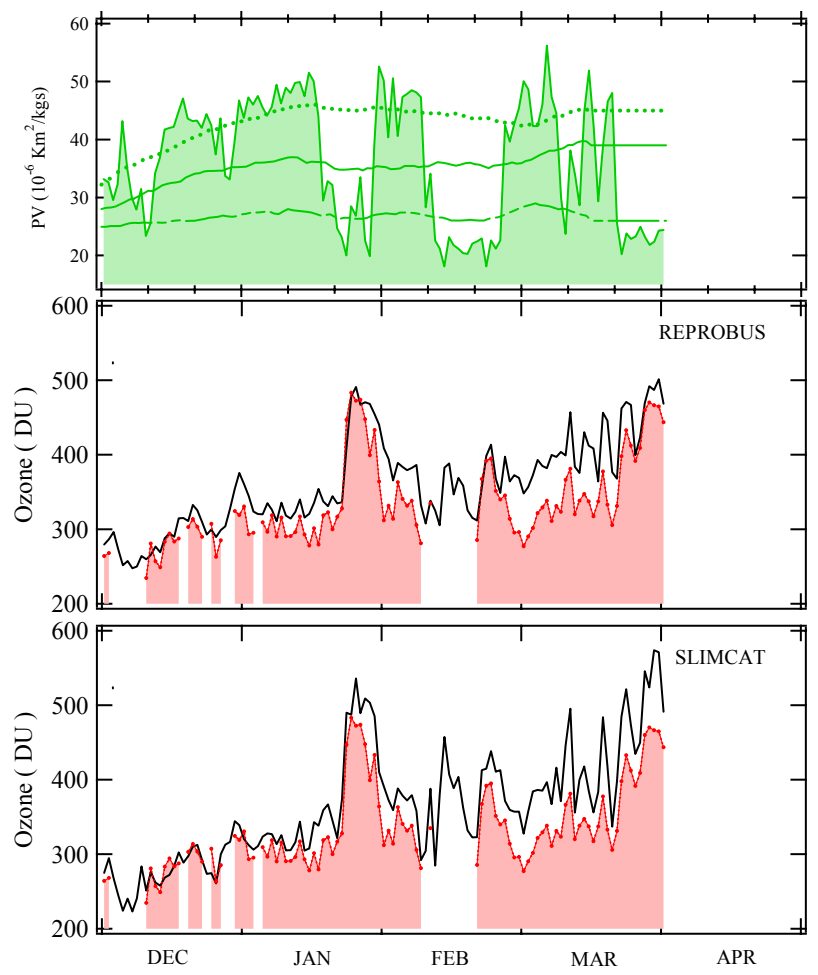

Fig. 1. Upper panel: Potential vorticity at $475 \mathrm{~K}$ (green shaded area) and vortex boundary (poleward: dotted line, edge: solid line, equatorward: dashed line). Middle panel: Measured total ozone (pink shaded area) and passive ozone simulated by the REPROBUS CTM (solid black line) from 1 December 2002 until 1 April 2003 above Sodankyla in Northern Finland. Bottom panel: same but for SLIMCAT. Some data are missing for various technical reasons or removed because of the presence of PSC particularly in early December.

procedure suggested by Nash et al. (1996). This procedure provides three limits: an "equatorward boundary", a "vortex edge", and a "poleward boundary". A serie of tests has shown that the best choice is the use of the vortex edge. Indeed, the use of the poleward boundary instead eliminates the measurements at the edge of the vortex, the only vortex region illuminated near the winter solstice where ozone loss occurs more frequently. While a larger selection by using the equatorward limit introduces a larger noise in the results likely due to some out vortex observations at levels other than $475 \mathrm{~K}$ when the vortex is tilted. In the following, the selection criteria is thus the vortex edge at $475 \mathrm{~K}$ (approx. $17 \mathrm{~km}$ ), the altitude of the maximum of ozone concentration and thus of the maximum contribution to the column. The broad geographical distribution of the SAOZ stations allows having in general one or more of them located in the vortex on a given day.

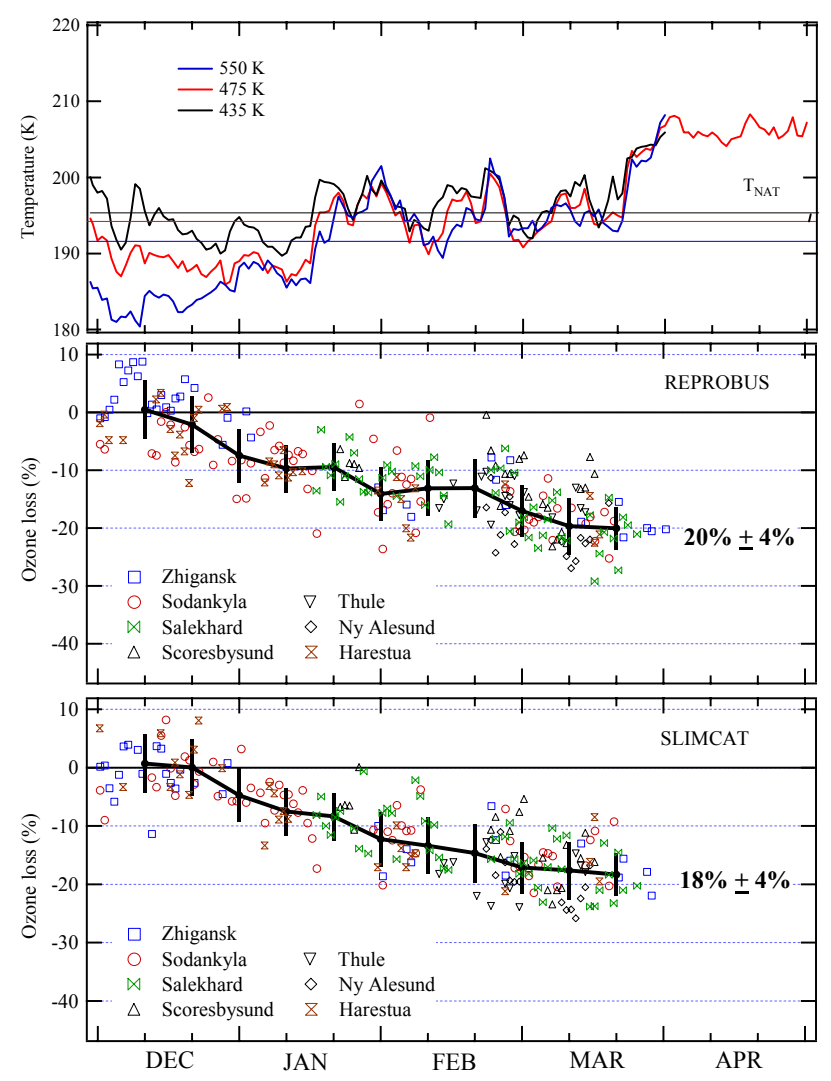

Fig. 2. Top panel: ECMWF minimum temperature in the Arctic at $550 \mathrm{~K}, 475 \mathrm{~K}$ and $435 \mathrm{~K}$ and limits of $\mathrm{T}_{N A T}$ formation. Middle panel: total ozone reduction inside the vortex at the SAOZ Arctic stations (symbols) using REPROBUS passive ozone, 10-day average (solid line) and standard deviation (error bars) from 1 December 2002 until end of March 2003. Bottom: same using SLIMCAT.

\section{Ozone loss above SAOZ stations in 2002/2003}

Figure 1 shows the evolution of the ozone column and the location of the vortex at Sodankyla in Northern Finland between 1 December 2002 and 31 March 2003. The middle panel displays the SAOZ ozone column (pink shaded area) and the passive ozone column simulated by REPROBUS (solid black line) and the lower panel, the same for SLIMCAT. In addition, the upper panel displays PV at $475 \mathrm{~K}$ above the station (green shaded area) and in dotted, solid and dashed lines the PV at the three boundaries of the vortex, poleward, edge and equatorward respectively. The two models capture well the short-term ozone fluctuations related to the reversible vertical motions of the tropopause following the propagation of planetary waves. Transitions between the inside and the outside of the vortex could also be clearly seen, especially during the second half of January when the vortex moved away from the station and high ozone columns are reported. A significant difference progressively builds up between SAOZ and modelled passive ozone indicative 


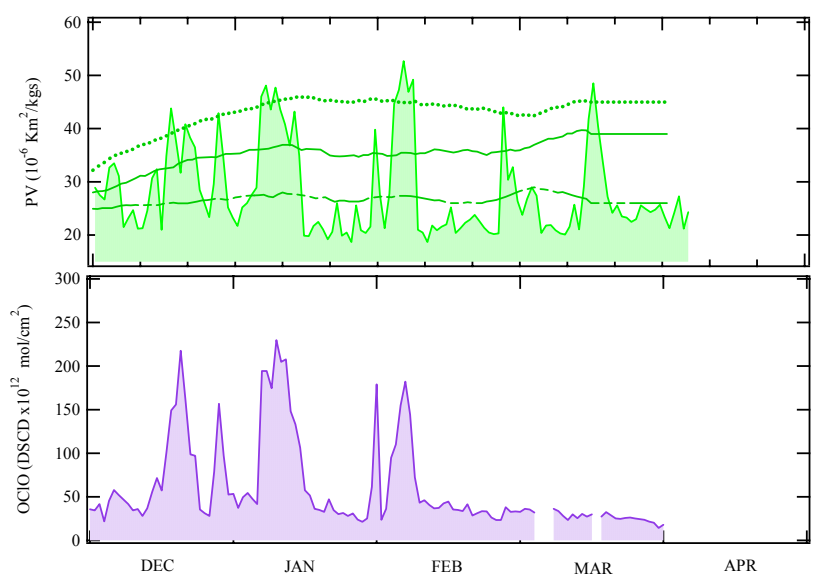

Fig. 3. Top panel: $\mathrm{PV}$ at $475 \mathrm{~K}$ and limit of vortex (as on Fig. 1). Bottom panel: Time series of OClO Differential Slant Columns (91-80 $\left.{ }^{\circ} \mathrm{SZA}\right)$ at Harestua in Southern Norway from 1 December 2002 until end of March 2003.

of a chemical reduction. By mid-March, before the end of the simulation, the difference in the vortex with both REPROBUS and SLIMCAT reaches 90 Dobson Units (DU), about $20 \%$. However, a noticeable difference appears between the two models outside the vortex. In contrast to the inside where the columns are very similar, SLIMCAT amplifies the ozone outside the vortex compared to REPROBUS and SAOZ as well. Such difference may be related to the different methods used by both models to calculate the vertical transport (ECMWF vertical winds or computed heating rates).

Similar observations are reported at the other stations (not shown) though the total ozone and hence the absolute loss expressed in DU can vary from one station to another because of the change of tropopause height. In the following, the loss at the various stations is thus compared in relative and not absolute units.

The relative percent ozone reduction in the vortex at the seven stations combined altogether is shown in Fig. 2 in the middle panel for REPROBUS and in the lower one for SLIMCAT. Also displayed in the plots are 10-day running means with error bars representing standard deviations. The upper panel shows the minimum ECMWF temperature north of $30^{\circ} \mathrm{N}$ at three levels $(435,475$ and $550 \mathrm{~K})$ and the temperatures of NAT (Nitric Acid Trihydrate) PSC formation at each level.

At $550 \mathrm{~K}$, the temperature was well below $\mathrm{T}_{N A T}$ at $192 \mathrm{~K}$ from mid-November until mid-January, while at lower levels the period of $\mathrm{T}<\mathrm{T}_{N A T}(195 \mathrm{~K}$ at $475 \mathrm{~K}$ and $196 \mathrm{~K}$ at $435 \mathrm{~K}$ ) started later in early December. By mid-January, three minor stratospheric warming could be observed during which the temperature increased, the first around 15 January lasting for 20 days, the second around 10 February for 15 days and the last around 5 March for 10 days. The final warming occurred around 20 March.
The cumulative ozone losses derived using the two models are very similar. On average, the standard deviation of all measurements within a 10 -day period is $4 \%$ on both evaluations. A number of processes could contribute: i) inhomogeneities of the ozone loss in the vortex; ii) systematic differences between SAOZ instruments $(<3 \%)$; iii) AMF fluctuations because profile shapes differences $(<3 \%)$; iv) small mismatches between the location of measurements and the simulations when the ozone is varying fast, v) presence of thin PSC resulting in a drop of ozone not totally removed by the colour index procedure; vi) small shifts in the location of the ECMWF vortex edge compared to the real atmosphere; and vii) out vortex ozone at altitude above $475 \mathrm{~K}$, the selection level, because of the smaller size of the vortex.

Consistent with the presence of PSCs, the loss started very early during the second half of December at an average rate of $0.4 \pm 0.2 \%$ per day, reaching $6-8 \%$ by the end of the month and about $10 \%$ by 10 January. The process then stopped for a 10-day period when the stratosphere warmed, to restart between 20-31 January, at a rate of $0.4 \pm 0.2 \%$ per day. This was followed by twenty days of stabilisation (SAOZ/REPROBUS) or of slow decrease at $0.1 \%$ per day (SAOZ/SLIMCAT). At last, a third period of destruction at $0.4 \pm 0.2 \%$ per day could be observed between 20 February and 10 March in coincidence with a further cooling of the stratosphere. The cumulative loss at the end of the winter reached $20 \pm 4 \%$ or $\sim 94 \pm 20 \mathrm{DU}$ (SAOZ/REPROBUS) or $18 \pm 4 \%$ or $\sim 86 \pm 23$ DU (SAOZ/SLIMCAT). Half of it occurred before mid-January.

\section{Other reports}

Several authors have been reporting early PSCs, chlorine activation and ozone loss in December 2002. The presence of PSCs could be detected as early as 3 and 7 December over Northern Sweden by balloon-borne instruments (Larsen et al., 2004). A very early chlorine activation and ozone loss has been reported by Tilmes et al. (2003) from the analysis of the HALOE (Halogen Experiment on UARS) data using the TRAC (ozone-tracer correlation) method, confirmed by the very low $\mathrm{HCl}$ mixing ratio measured at $520 \mathrm{~K}$ in the vortex by the MkIV balloon instrument flown over Northern Sweden on 16 December. The occurrence of early chlorine activation is also supported by the measurements of the ODIN SubMillimeter Radiometer (SMR) satellite instrument showing night-time $\mathrm{ClO}$ amounts of about $0.3-0.6 \mathrm{ppbv}$ between $450 \mathrm{~K}$ and $525 \mathrm{~K}$ on 9-10 December (Urban et al., 2004), implying daytime amounts of the order of $1 \mathrm{ppbv}$. The event is also confirmed by the presence of high OClO levels observed in December by the UV-Visible spectrometer at Harestua in Southern Norway (Fig. 3) when the vortex was passing above the station and by the ERS-2/GOME (Global Ozone Monitoring Experiment on board ERS-2 satellite) observations displaying an unusual high activation in December (http:// 
www.iup.physik.uni-bremen.de/gomenrt2003/) compared to the previous winters (Wagner et al., 2001, 2002; WMO assessment, 2003).

Finally, according to Tilmes et al. (2003) on 19-26 January (first HALOE available profiles inside vortex during that winter), an average partial column ozone reduction of $23 \pm 9$ DU (about 10\%) would have occurred between 380 and $550 \mathrm{~K}$ in the outer Vortex with a maximum value reaching $33 \pm 8 \mathrm{DU}$ (about $13 \%$ ).

The early ozone loss observed by the SAOZ network in late December and early January is thus very consistent with the presence of PSCs, chlorine activation, and ozone loss reported by other authors.

\section{Comparison to other winters}

The cumulative ozone loss of the winter 2002/2003 is compared in Fig. 4 to that reported during all other winters between 1993/1994 and 2003/2004 by comparison between SAOZ and REPROBUS, though a possible bias could exist because of a change in the model in 1999. Indeed by that date, ECMWF with which REPROBUS is forced, moved from 31 vertical levels extending up to $10 \mathrm{hPa}$ to 60 levels up to $0.1 \mathrm{hPa}$. Figure 4 also displays the minimum ECMWF temperature north of $30^{\circ} \mathrm{N}$ at 550 and $475 \mathrm{~K}$.

The 20\% loss reported during the winter 2002/2003 is among the average amplitude of the cold winter reductions observed during the decade, after that of the two extremely long lasting winters of 1994/1995 and 1995/1996 (Goutail et al., 1998, 1999, 2000; Harris et al., 2002). But it is the year with 1993/1994 when the ozone depletion has started the earliest in the series, in coincidence with the coldest December average stratospheric temperature. The question is to know how well such early winter ozone losses could be captured by photochemical models.

\section{Photochemical model simulations of 2002/2003}

The two models, REPROBUS and SLIMCAT, have been run with their full current chemical package to examine how much of the observed loss could be captured. However, before that, their chemical characteristics will be briefly summarised.

\subsection{REPROBUS}

The chemical rate constants and absorption cross-sections are those recommended by the latest JPL compilation (Sander et al., 2003). The total chlorine is set to $3.6 \mathrm{ppb}$, while the total bromine is 20 ppt. $\mathrm{Cl}_{2} \mathrm{O}_{2}$ cross-sections are those given in the recommendation. They are not extrapolated to longer wavelengths. PSCs are assumed to be in thermodynamic equilibrium. The composition of liquid aerosols
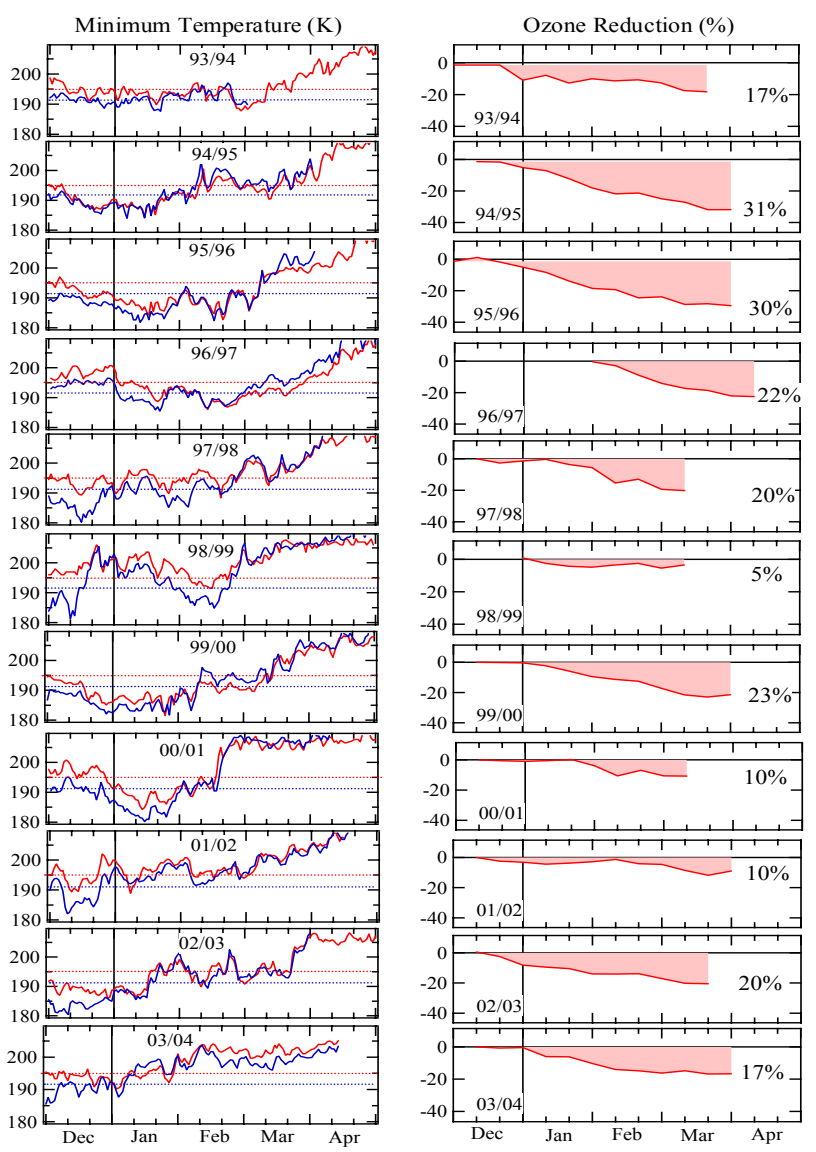

Fig. 4. Left: minimum ECMWF temperature at $475 \mathrm{~K}$ (red) and $550 \mathrm{~K}$ (blue) north of $30^{\circ} \mathrm{N}$ and limits for NAT PSC formation. Right: Total ozone reduction in the vortex since 1993/1994 from the measurements of the SAOZ stations by comparison to REPROBUS (shaded pink).

is calculated analytically as a function of temperature, pressure, and the gas phase amounts of $\mathrm{H}_{2} \mathrm{O}$ and $\mathrm{HNO}_{3}$. Ice is assumed to incorporate NAT as a co-condensate, removing nitric acid from the vapour phase.

REPROBUS was initialised on 1 July 2002 using a June zonal climatology from a 5-year run coupled to the ARPEGE general circulation model (see WMO 1998 assessment, Chapter 12). The sulphate aerosol content is derived from SAGE-II measurements. The ozone field is reinitialised from the ECMWF ozone analysis on 1 December 2002.

\subsection{SLIMCAT}

As already said above, SLIMCAT has been recently modified to use a hybrid $\sigma-\theta$ coordinate and has been extended down to the surface: this is the version used in this study. The SLIMCAT gas-phase and heterogeneous chemistry modules, including liquid aerosols, NAT and ice particles, are described in Chipperfield (1999). The total chlorine is set to $3.7 \mathrm{ppb}$, while the total bromine is $21 \mathrm{ppt}$. The 


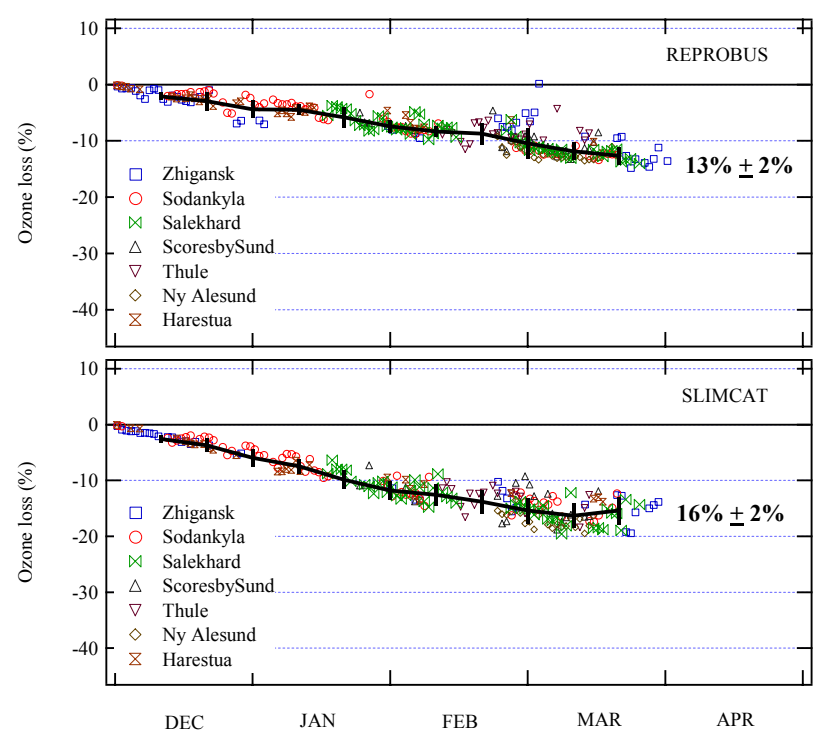

Fig. 5. REPROBUS (top panel) and SLIMCAT (bottom panel) simulated ozone loss in the vortex at the SAOZ Arctic stations (symbols), 10-day average (solid line) and standard deviation (error bars) from 1 December 2002 until end of March 2003.

$\mathrm{ClO}+\mathrm{ClO}$ rate from Sander et al. (2003) has been used. All model photochemical data were taken from this except for the absorption cross sections of $\mathrm{Cl}_{2} \mathrm{O}_{2}$. For this, the data of Burkholder et al. (1990) extended to $450 \mathrm{~nm}$ by extrapolation have been used. PSCs are assumed to be in thermodynamic equilibrium, with no modification of the model temperature to account for supersaturation. The composition of liquid aerosols (containing $\mathrm{HNO}_{3}, \mathrm{H}_{2} \mathrm{SO}_{4}, \mathrm{H}_{2} \mathrm{O}$ and $\mathrm{HCl}$ ) is calculated analytically. NAT is formed at the equilibrium NAT saturation temperature and the presence of ice is tested using the saturation vapour pressure of water over ice. Ice is assumed to incorporate NAT as a co-condensate, removing nitric acid from the vapour phase. A simple NAT-based denitrification scheme is used (see Davies et al., 2001; Feng et al., 2005).

SLIMCAT was initialized on 1 December 2002 from an ECMWF-forced multi-annual run which started in 1989.

\section{Modelled loss}

The ozone loss of the winter 2002/2003 above the SAOZ stations has been simulated by REPROBUS and SLIMCAT. For better consistency with observations, only simulations corresponding to existing measurements $\left(\mathrm{SZA}<91^{\circ}\right.$ at noon) are considered. Figure 5 shows the results of the simulations. Both models indicate a significant ozone reduction, but of smaller amplitude in REPROBUS. That of SLIMCAT $(16 \pm 2 \%)$ is comparable to the loss derived by the comparison of its passive run to SAOZ $(18 \pm 4 \%)$. In contrast, that of REPROBUS is significantly reduced $(13 \pm 2 \%$ instead of $20 \pm 4 \%$ ). Although both indicate an ozone de- struction starting in December, the main difference between them comes from its amplitude until mid-January, of 9\% for SLIMCAT (similar to that derived from SAOZ) and only $5 \%$ for REPROBUS (half of that derived from SAOZ). Since the transport is identical in the passive and full chemistry runs, the difference must come from the chemistry.

Figures 6 and 7 provide more insight on the development of the REPROBUS ozone loss respectively at $550 \mathrm{~K}$ and $475 \mathrm{~K}$ from 5 December to 15 January. At the upper level, $550 \mathrm{~K}$, the vortex is well formed at the beginning of the period, with a large PSC surface area diagnosed on the European side. A substantial chlorine and bromine activation is calculated at the edge of the vortex, extending over the whole vortex by 25 December. A very similar evolution though a little delayed could be observed lower down at $475 \mathrm{~K}$. Absent on 5 December, a significant ozone loss is calculated on 25 December at the edge of the vortex. The loss is more abundant at $475 \mathrm{~K}$ where the illuminated portion of the polar vortex is larger than at $550 \mathrm{~K}$. The amplitude of the reduction further increases $(10 \%$ at $550 \mathrm{~K}, 8 \%$ at $475 \mathrm{~K})$ on 15 January when the surface of the vortex enlarges again and its edge moves to sunlit latitudes over Eastern Europe and Siberia.

Figures 8 and 9 provide similar plots of $\mathrm{HCl}, \mathrm{ClO}_{\mathrm{x}}$ and $\mathrm{O}_{3}$ loss for SLIMCAT on 5 December. Chlorine species are activated at the beginning of December not only at $550 \mathrm{~K}$ but also at $475 \mathrm{~K}$. It is obvious from the $\mathrm{HCl}$ and $\mathrm{ClO}_{\mathrm{x}}$ distribution that SLIMCAT infers more chlorine activation than REPROBUS on 5 December, and thus more ozone loss.

Although both models show an activation of chlorine in early December, the magnitude of this activation is quantitatively different. The reason for the difference is difficult to identify precisely. The models did their own experiment, which were aimed to be realistic, but many details were different. Besides the vertical transport approach, there are also differences in the chemistry. Recent changes made to SLIMCAT to increase polar $\mathrm{O}_{3}$ loss such as $\mathrm{Cl}_{2} \mathrm{O}_{2}$ cross sections from Burkholder et al. (1990) has been tested by REPROBUS. This gives an additional loss of only $0.5 \%$ by mid-January. REPROBUS ignores the formation of NAT in the simulation presented here (STS/Ice only). A test has been performed to consider NAT but the additional loss was negligible, less than $0.03 \%$ by mid-January.

In conclusion, both models are capturing an ozone loss during the winter 2002/2003, but of lesser amplitude for REPROBUS (13\%) than for SLIMCAT (16\%). The 3\% difference between the models lies in December and is already observed on 5 December 2002. The Cly and Bry initialisations being very similar, the temperature being identical (ECMWF), the difference between model may be due i) to the PSC formation scheme, as suggested by the different activation rate in early December or ii) to the vertical transport which can provide more or less descent and thus a different redistribution of chlorine and bromine species inside the vortex. These hypotheses could not be solved in the frame of this paper but will be investigated further in the future. 
Date

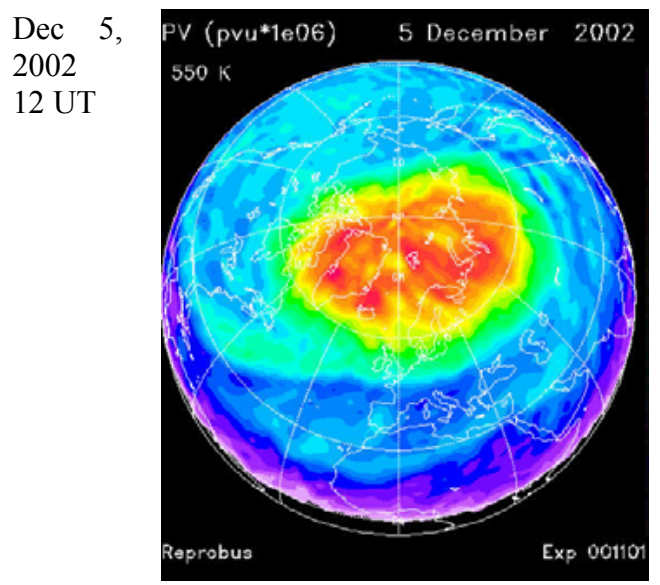

Dec 25,

2002

12 UT

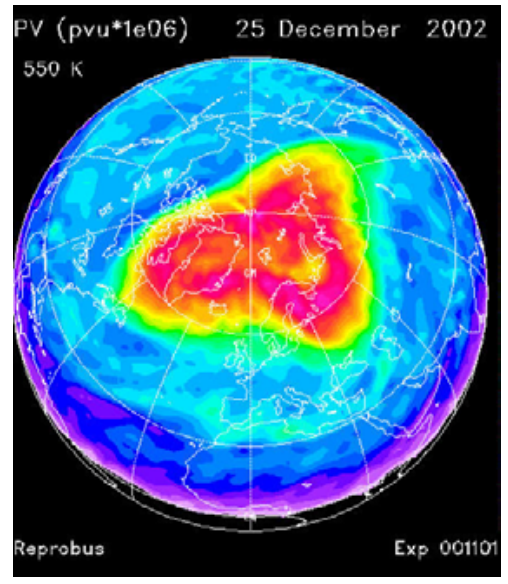

Jan 15 ,

2003

12 UT

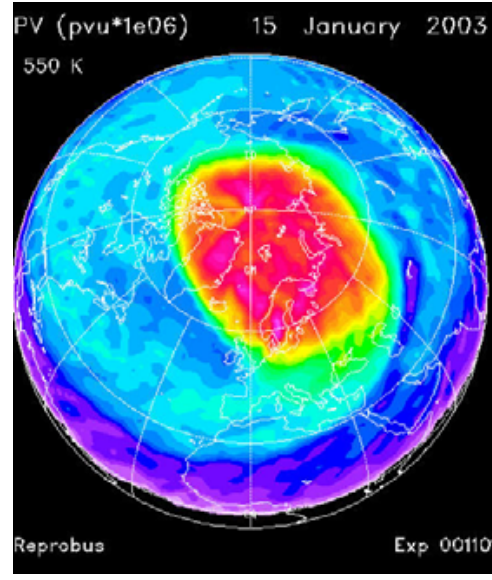

Scale

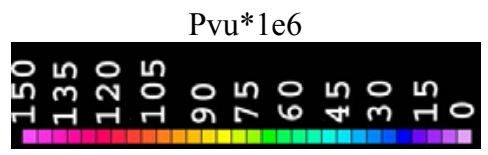

PSC Surface area
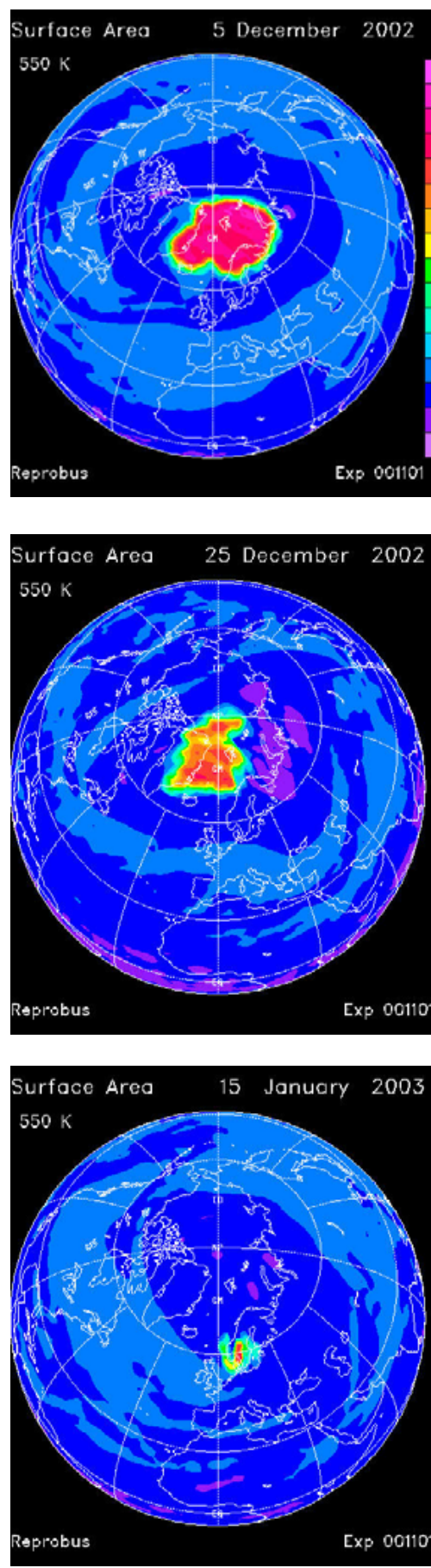

Surface area $\left(\mu \mathrm{m}^{2} \mathrm{~cm}^{-3}\right)$

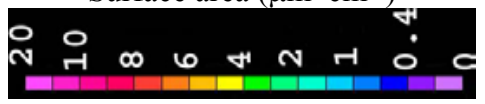

$\mathrm{BrOx}$
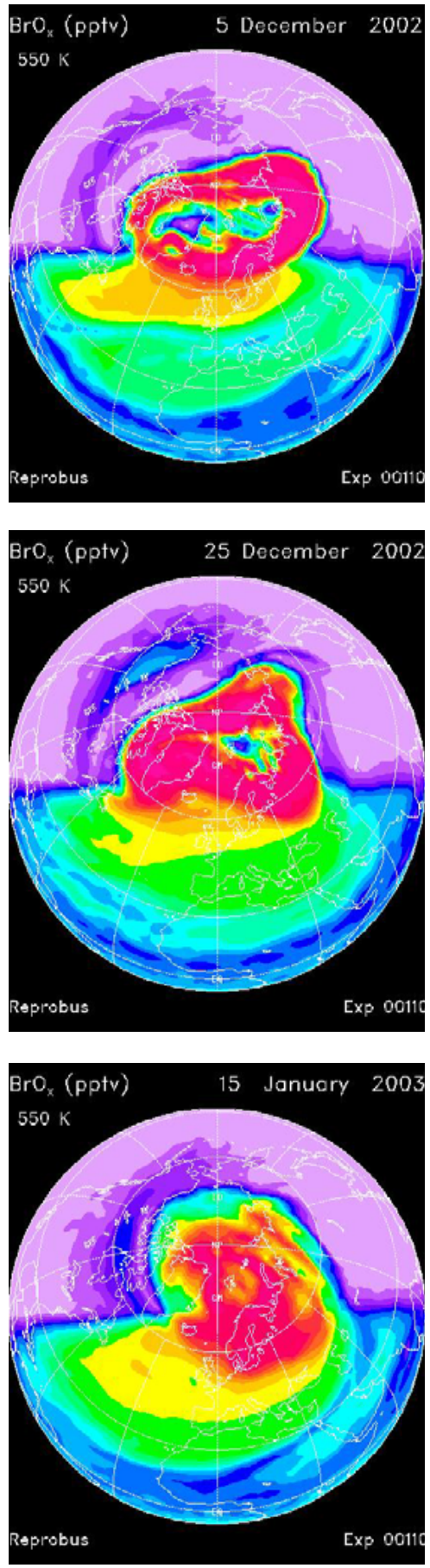

pptv

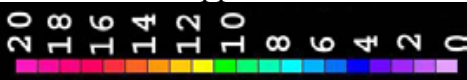

Fig. 6a. Vortex, PSC surface area and $\mathrm{BrO}_{\mathrm{x}}$ from REPROBUS at $550 \mathrm{~K}$. Top panel: 5 December 2002. Middle panel: 25 December 2002. Bottom panel: 15 January 2003. 
Date
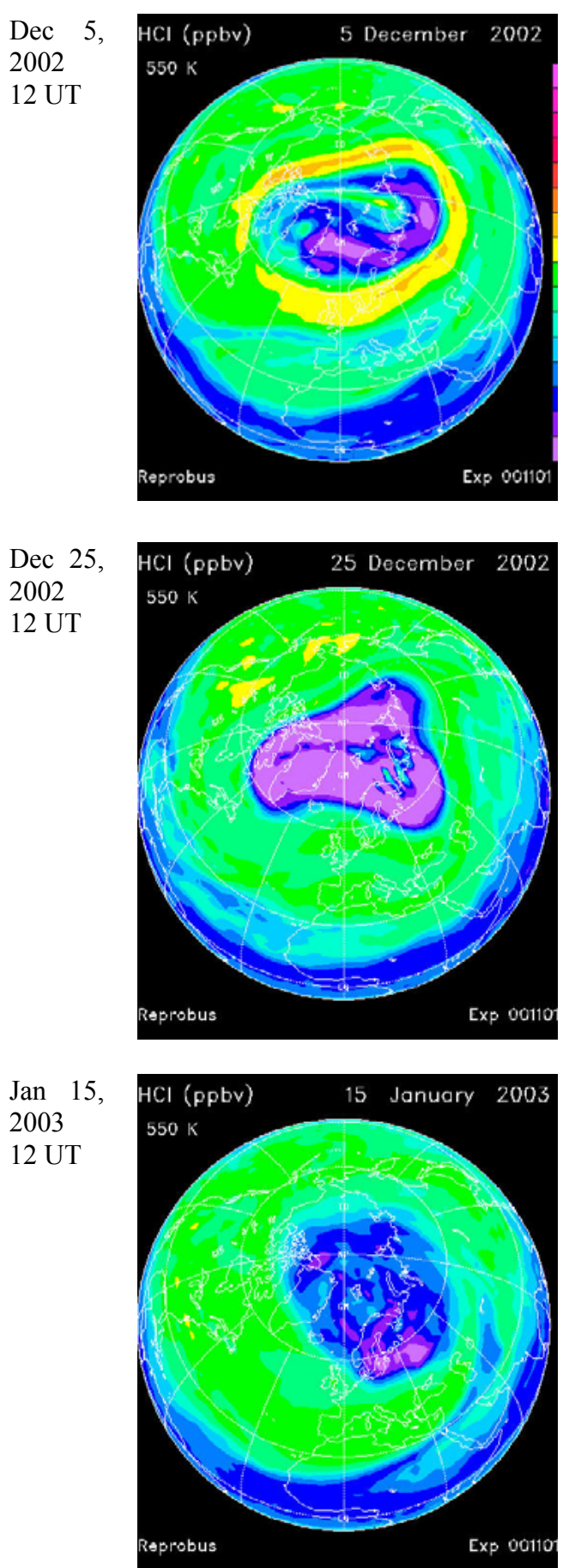

Scale

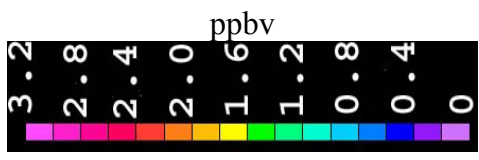

$\mathrm{ClOx}$
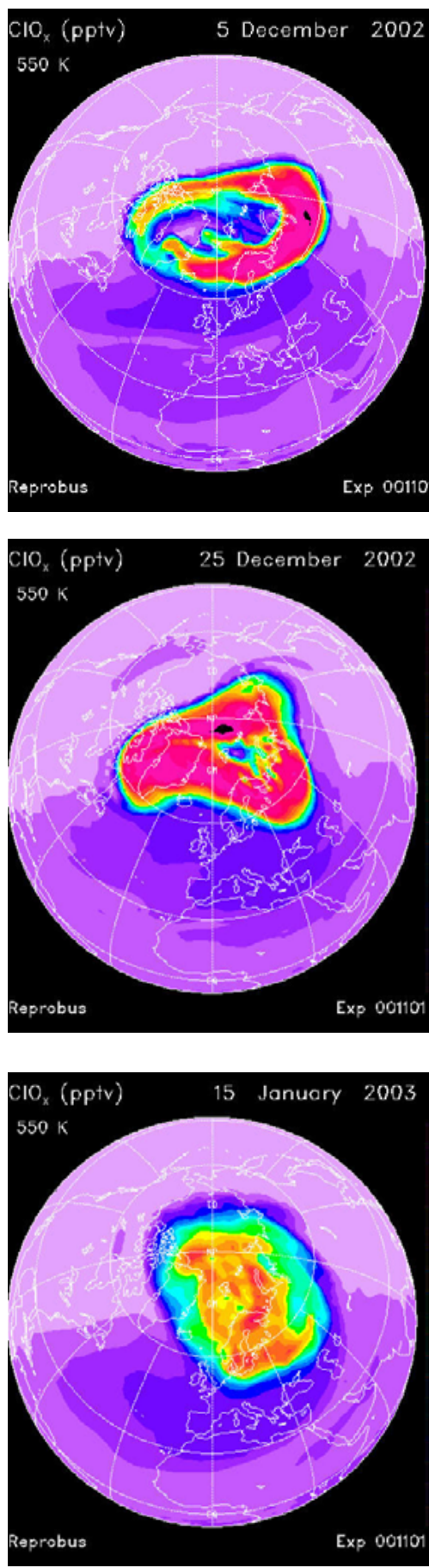

pptv

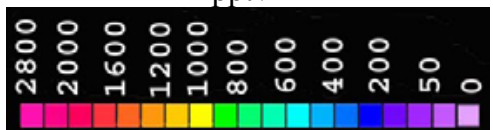

O3 Loss
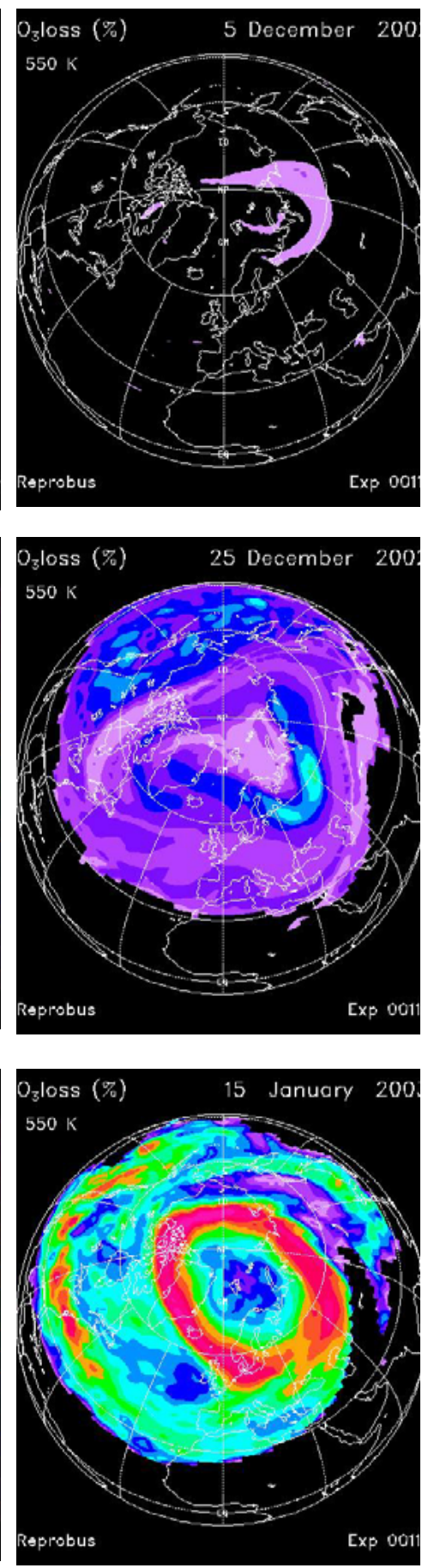

$\%$

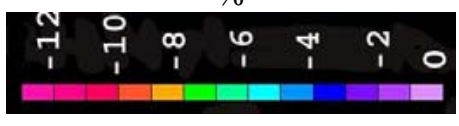

Fig. 6b. $\mathrm{HCl}, \mathrm{ClO}_{\mathrm{x}}$, and $\mathrm{O}_{3}$ loss from REPROBUS at $550 \mathrm{~K}$. Top panel: 5 December 2002. Middle panel: 25 December 2002 . Bottom panel: 15 January 2003. 
Date

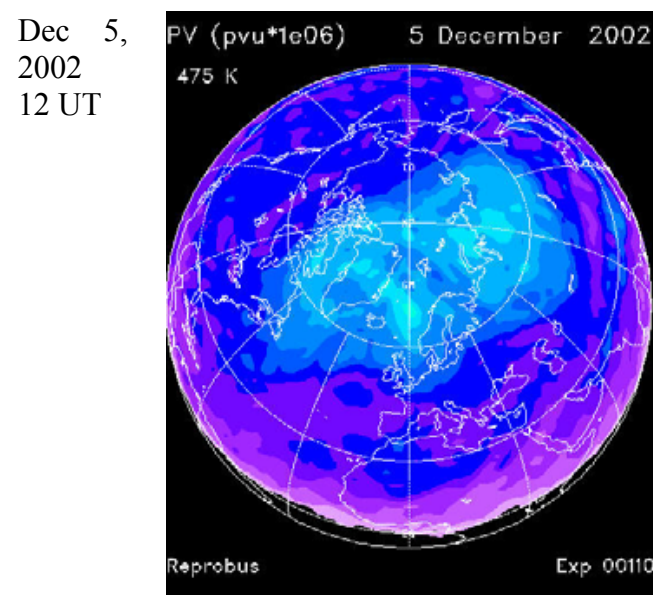

Dec 25,

2002

12 UT
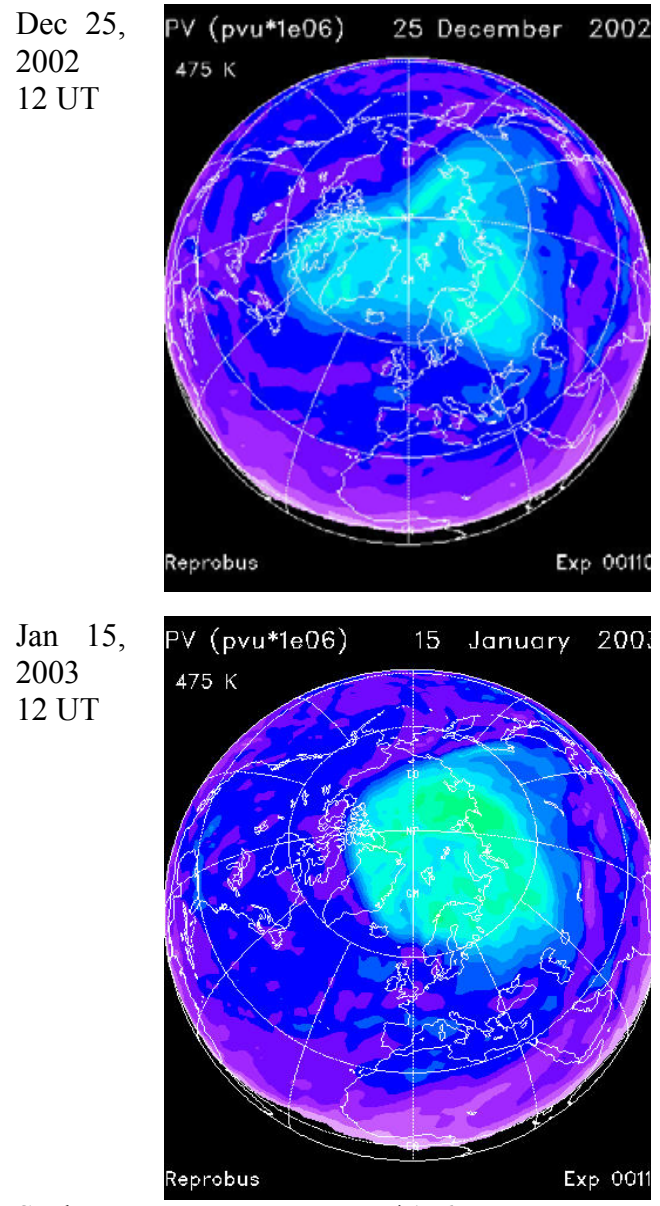

Scale

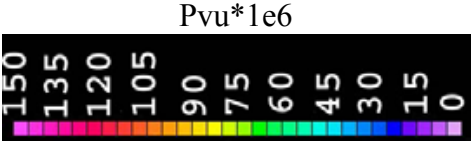

PSC Surface area
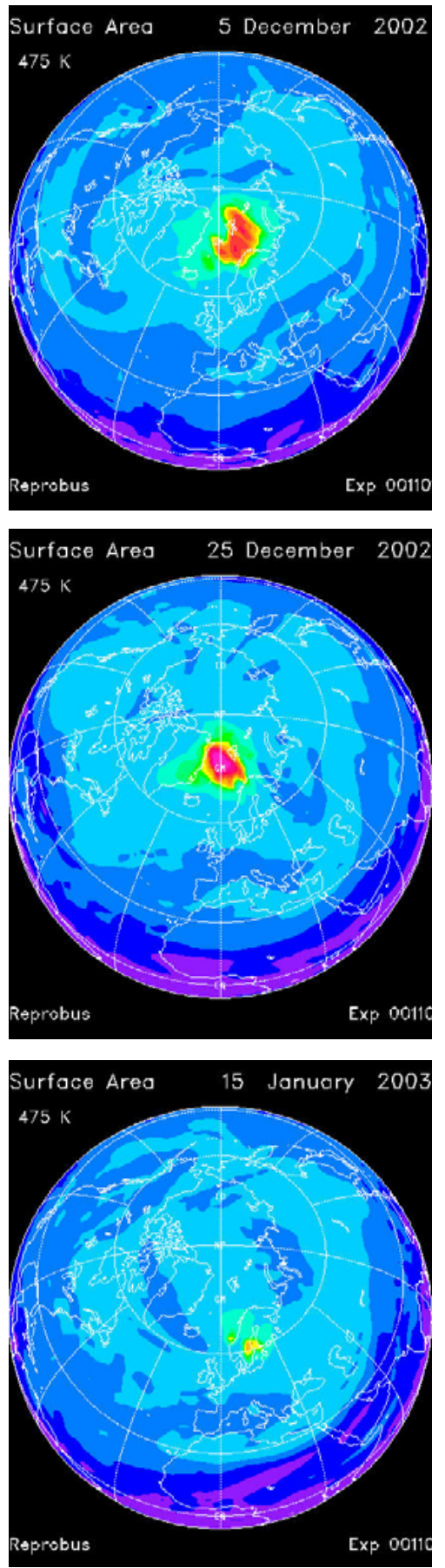

Surface area $\left(\mu \mathrm{m}^{2} \mathrm{~cm}^{-3}\right)$

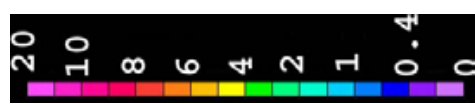

$\mathrm{BrOx}$
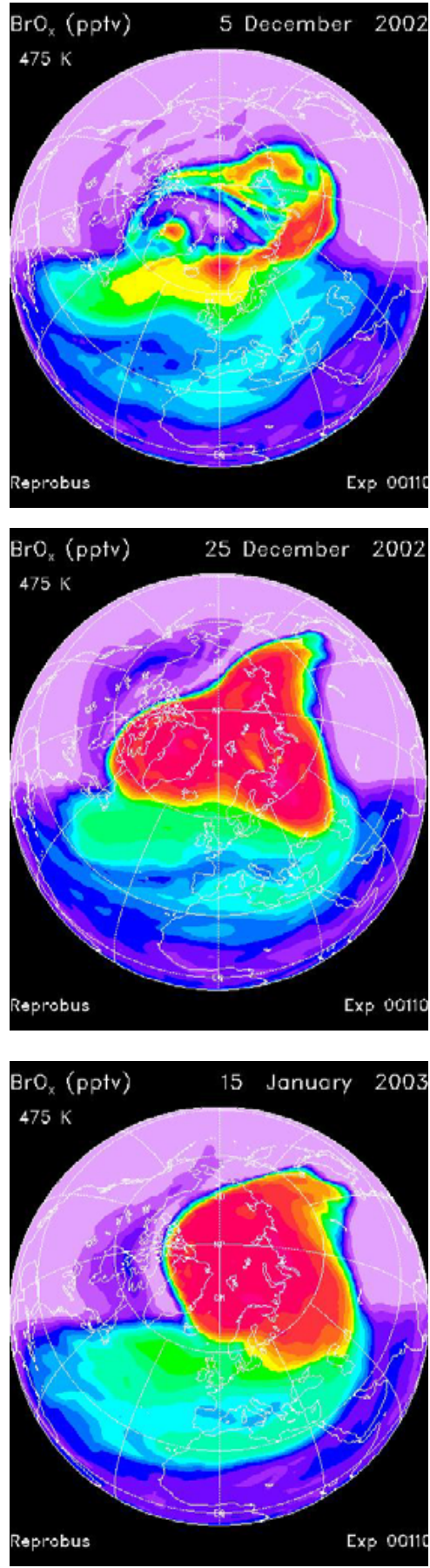

Pptv

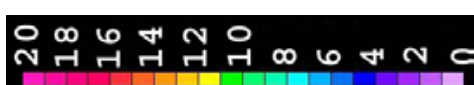

Fig. 7a. Vortex, PSC surface area and $\mathrm{BrO}_{\mathrm{x}}$ from REPROBUS at $475 \mathrm{~K}$. Top panel: 5 December 2002. Middle panel: 25 December 2002. Bottom panel: 15 January 2003. 
Date

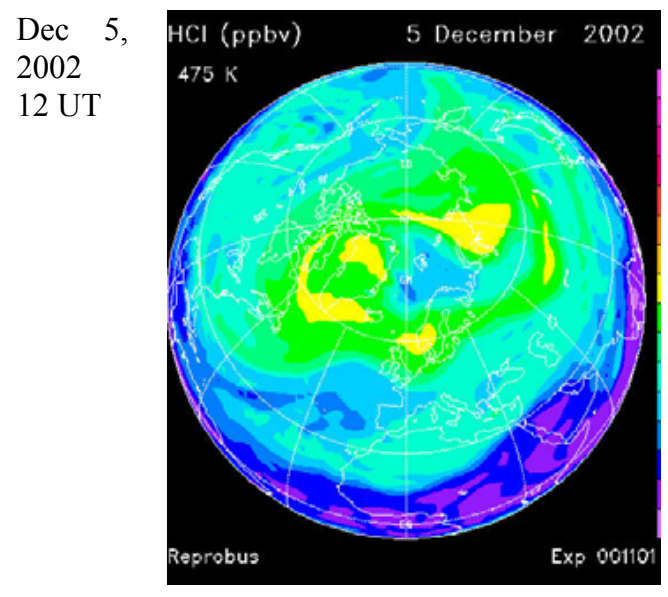

Dec 25, 2002

12 UT

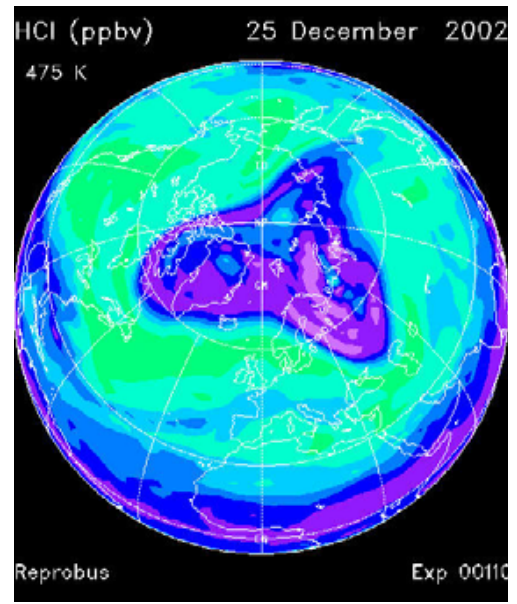

Jan 15, $\mathrm{HCl}$ (ppbv) 15 Januery 2003

2003

12 UT

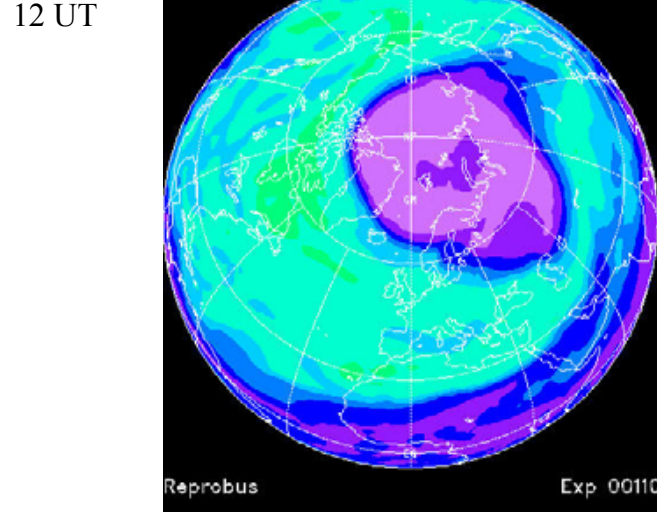

Scale

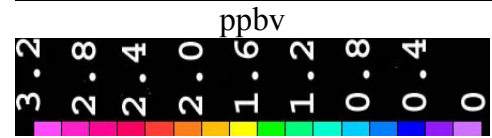

ClOx
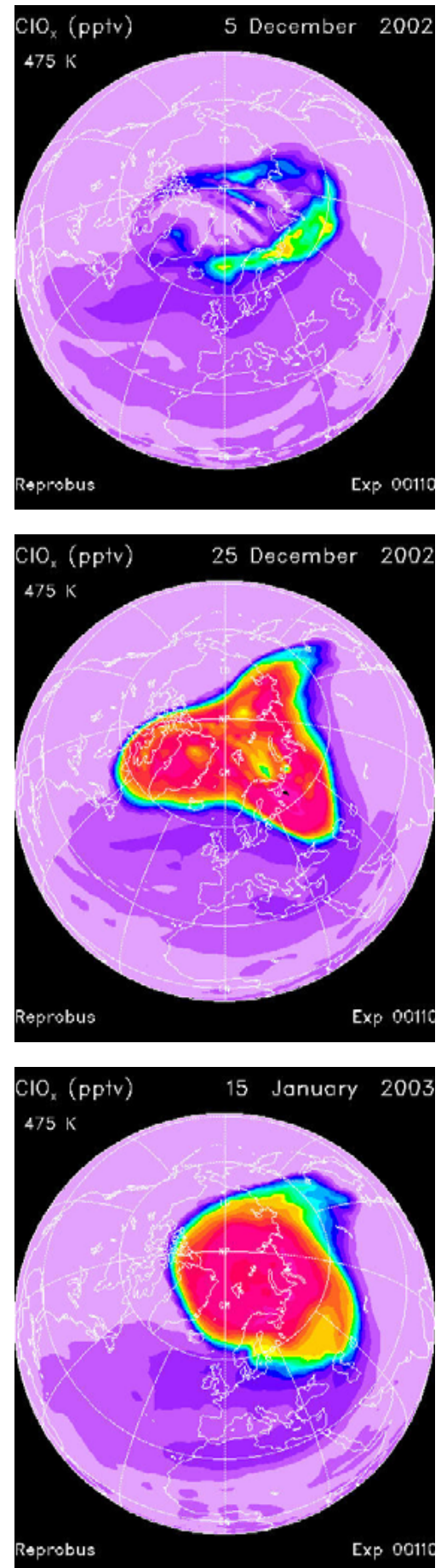

pptv

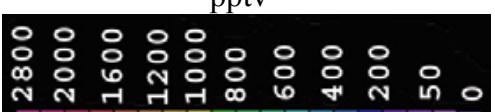

O3 Loss
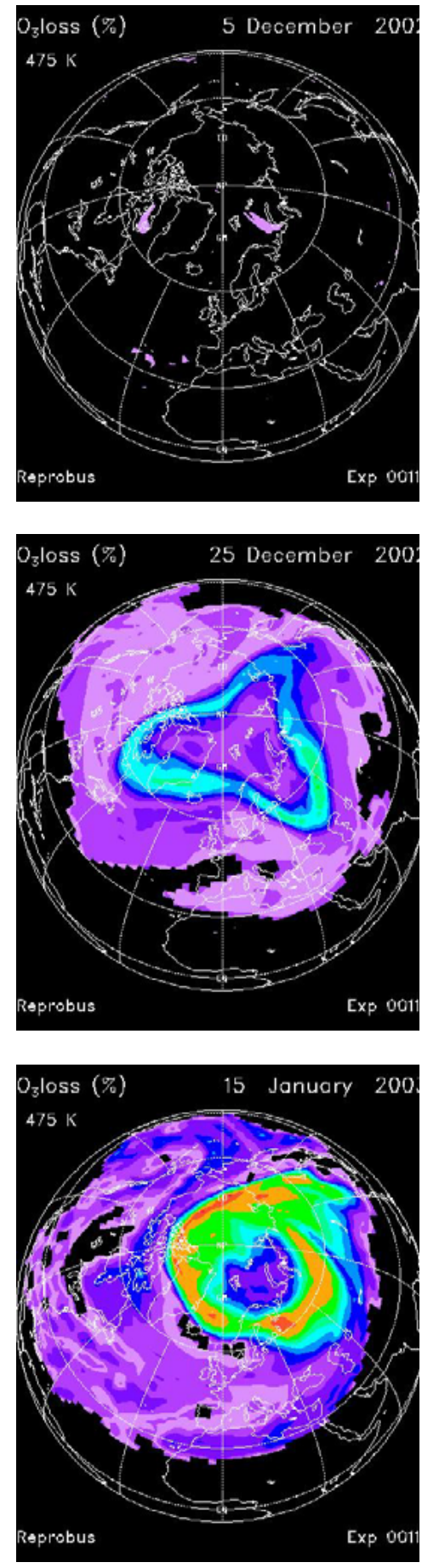

$\%$

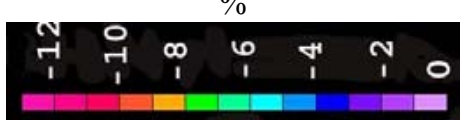

Fig. 7b. $\mathrm{HCl}, \mathrm{ClO}_{\mathrm{x}}$, and $\mathrm{O}_{3}$ loss from REPROBUS at $475 \mathrm{~K}$. Top panel: 5 December 2002. Middle panel: 25 December 2002. Bottom panel: 15 January 2003. 
Date

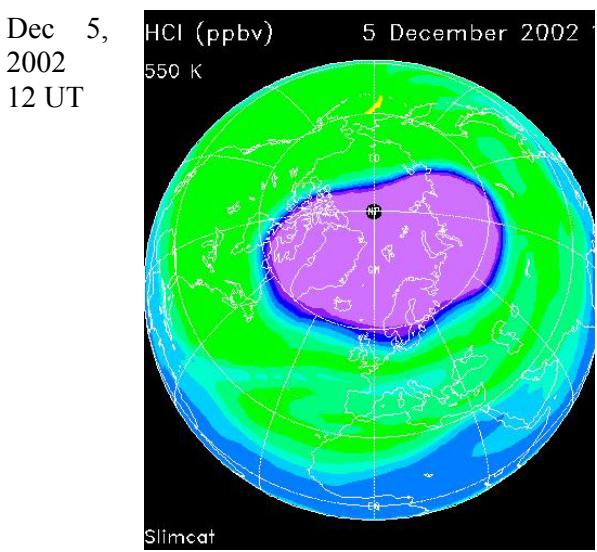

Scale

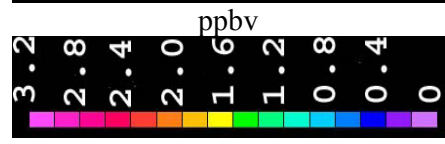

$\mathrm{ClOx}$

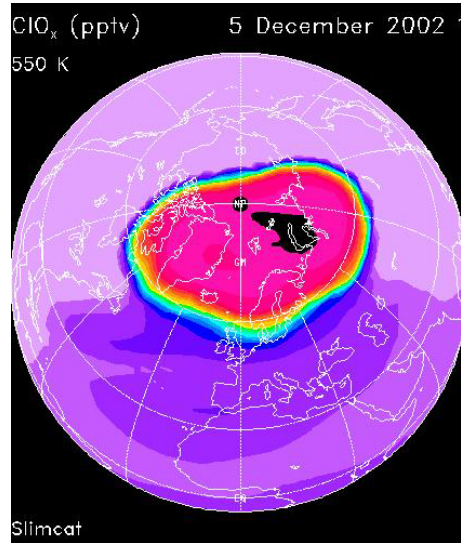

pptv

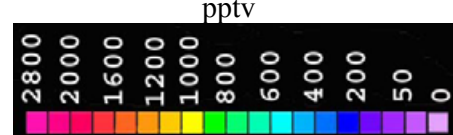

O3 Loss

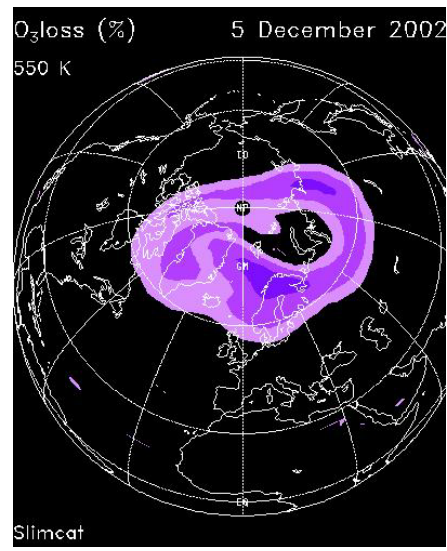

$\%$

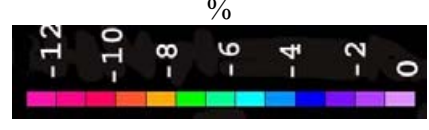

Fig. 8. $\mathrm{HCl}, \mathrm{ClO}_{\mathrm{x}}$, and $\mathrm{O}_{3}$ loss from SLIMCAT at $550 \mathrm{~K}$ on 5 December 2002.

Date

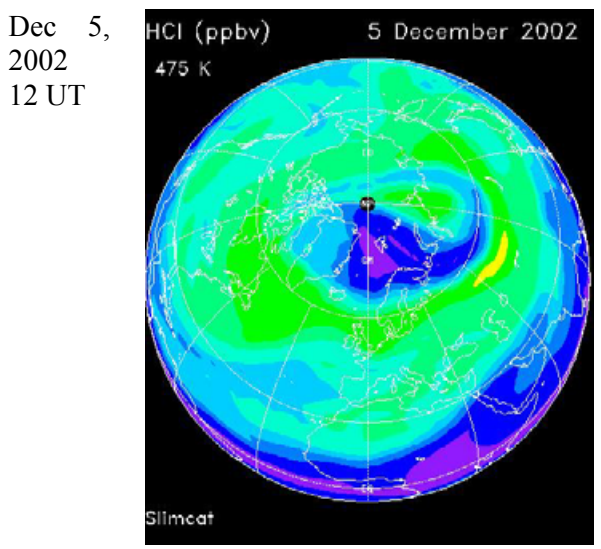

Scale

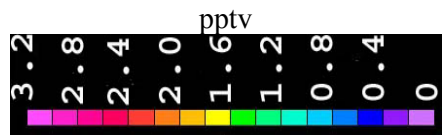

$\mathrm{ClOx}$

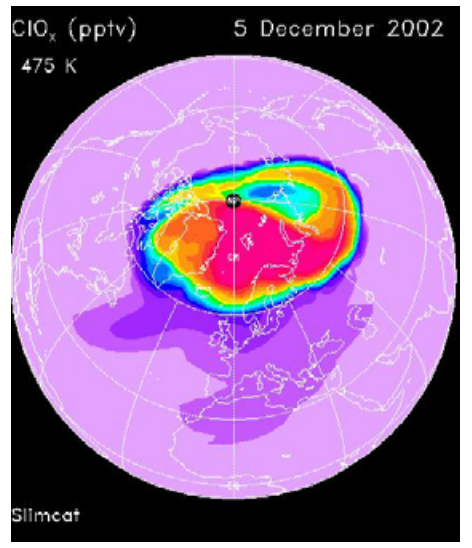

pptv

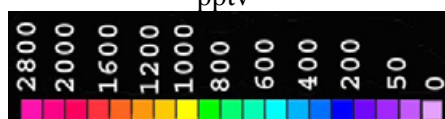

O3 Loss

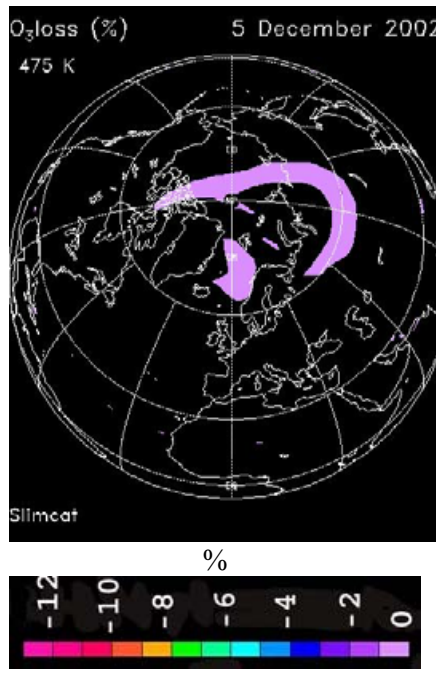

Fig. 9. $\mathrm{HCl}, \mathrm{ClO}_{\mathrm{x}}$, and $\mathrm{O}_{3}$ loss from SLIMCAT at $475 \mathrm{~K}$ on 5 December 2002.

Acknowledgements. The authors thank the SAOZ stations operators, ECMWF for the meteorological data and E. Nash for vortex limits. This work was supported by the Centre National d'Etudes Spatiales (CNES), Services d'Observations de l'IPSL, the Programme National de Chimie de l'Atmosphere (PNCA) in France and the EC Environmental projects (SCUVS, SCUVS-III, SRS, TOPOZ III, THESEO /O3Loss, THESEO 2000 /EUROSOLVE, ENV-2001-QUILT). The SAOZ stations are part of the NDSC (Network for Detection of Stratospheric Changes).

Edited by: K. Carslaw

\section{References}

Briegleb, B. P.: Delta-Eddington Approximation for Solar Radiation in the, NCAR Community Climate Model, J. Geophys. Res. 97, 7603-7612, 1992.

Burkholder J. B., Orlando, J. J., and Howard, C. J.: Ultravioletabsorption cross-sections of $\mathrm{Cl} 2 \mathrm{O} 2$ between 210 and $410 \mathrm{~nm}$, J. Phys. Chem., 94, 687-695, 1990.

Chipperfield, M. P., Lee, A. M., and Pyle, J. A.: Model calculations of ozone depletion in the Arctic polar vortex for 1991/92 to 1994/95, Geophys. Res. Lett., 5, 559-562, 1996. 
Chipperfield, M. P. and Pyle, J. A.: Model sensitivity studies of Arctic ozone depletion, J. Geophys. Res., 103, 28 389-28 403, 1998.

Chipperfield, M. P.: Multiannual simulations with a ThreeDimensional Chemical Transport Model, J. Geophys. Res., 104, 1781-1805, 1999.

Davies, S., Chipperfield, M. P., Carslaw, K. S. , Sinnhuber, B.-M., Anderson, J. G., Stimpfle, R., Wilmouth, D., Fahey, D. W., Popp, P. J., Richard, E. C., von der Gathen, P., Jost, H., and Webster, C. R.: Modelling the Effect of Denitrification on Arctic Ozone Depletion During Winter 1999/2000, J. Geophys. Res., 107, 8322, doi:10.1029/2001JD000445, 2002. [printed 108(D5), 2003]

Feng, W., Chipperfield, M. P., Davies, S., Sen, B., Toon, G., Blavier, J. F., Webster, C. R., Volk, C. M., Ulanovsky, A., Ravegnani, F., von der Gathen, P., Jost, H., Richard, E. C., and Claude, H.: Three dimensional model study of the Arctic ozone loss in 2002/2003 and comparison with 1999/2000 and 2003/2004, Atmos. Chem. Phys., 5, 139-152, 2005,

SRef-ID: 1680-7324/acp/2005-5-139.

Goutail, F., Pommereau, J-P., Kyro, E., Rummukainen, M., Ericksen, P., Andersen, S., Kaastad-Hoiskar, B-A., Braathen, G.O., Dorokhov, V., Khattatov, V., van Roozendael, M., and de Maziere, M.: Total ozone reduction in the Arctic vortex during the winters of 1995/96 and 1996/97, Proc. 4th European Symposium on Polar Ozone, EC Air Pollution Research Report No. 66, edited by: Harris, N. R. P., Kilbane-Dawe, I., and Amanatidis, G. T., European Commission, 277-280, 1998.

Goutail, F., Pommereau, J-P., Phillips, C. Deniel, C., Sarkissian, A., Lefèvre, F., Kyro, E., Rummukainen, M., Ericksen, P., Andersen, S., Kaastad-Hoiskar, B.-A., Braathen, G., Dorokhov, V., and Khattatov, V.: Depletion of Column Ozone in the Arctic during the Winters 1993-94 and 1994-95, J. Atmos. Chem., 32, 1-34, 1999.

Goutail, F., Pommereau, J.-P., and Lefèvre, F.: Winter ozone loss in the Arctic and at mid-latitudes in 1998 and 1999 from the saoz ground-based network and balloon measurements, in: Proc. 5th Europ. Symp., EU Air Pollution Res. Rep. 73, Saint Jean de Luz (France), 1999, edited by: Harris, N. R. P., Guirlet, M., and Amanatidis, G. T., 433-436, 2000.

Harris, N. P. R., Rex, M., Goutail, F., Knudsen, B. M., Manney, G. L., Müller, R., and von der Gathen, P.: Comparison of Empirically Derived Ozone Losses in the Arctic Vortex, J. Geophys. Res., 107(D20), doi:10.1029/2001JD000482, 2002.

Hofmann, D. J., Deshler, T. L., Aimedieu, P., Matthews, W. A., Johnston, P. V., Kondo, Y., Sheldon, W. R., Byrne, G. J., and Benbrook, J. R.: Stratospheric clouds and ozone depletion in the arctic during January 1989, Nature, 340, 117-121, 1989.

Hofmann D. J. and Deshler, T.: Evidence from balloon measurements for chemical depletion of stratospheric ozone in the Arctic winter of 1989-90, Nature, 349, 300-305, 1991.

Larsen, N., Knudsen, B. M., Svendsen, S. H., Deshler, T., Rosen, J. M., Kivi, R., Weisser, C., Schreiner, J., Mauerberger, K., Cairo, F., Ovarlez, J., Oelhaf, H., and Spang, R.: Formation of solid particles in synoptic-scale Arctic PSCs in early winter 2002/2003, Atmos. Chem. Phys., 4, 2001-2013, 2004, SRef-ID: 1680-7324/acp/2004-4-2001.

Lefèvre, F., Brasseur, G. P., Folkins, I., Smith, A. K., and Simon, P.: Chemistry of the 1991-92 stratospheric winter: three dimensional model simulations, J. Geophys. Res., 99, 8183-8195,
1994.

Lefèvre, F., Figarol, F., Carslaw, K. S., and Peter, T.: The 1997 Arctic ozone depletion quantified from three dimensional model simulations, Geophys. Res. Lett., 25, 2425-2428, 1998.

Nash, E. R., Newman, P. A., Rosenfield, J. E., and Schoeberl, M. R.: An objective determination of the polar vortex using Ertel's potential vorticity, J. Geophys. Res., 101, 9471-9478, 1996.

Pommereau, J. P. and Goutail, F.: $\mathrm{O}_{3}$ and $\mathrm{NO}_{2}$ Ground-Based Measurements by Visible Spectrometry during Arctic Winter and Spring 1988, Geophys. Res. Lett., 891-894, 1988.

Roscoe, H. K, Johnston, P. V., Van Roozendael, M., Richter, A., Preston, K., Lambert, J. C., Hermans, C., de Kuyper, W., Dzenius, S., Winterath, T., Burrows, J., Sarkissian, A., Goutail, F., Pommereau, J. P., d'Almeida, E., Hottier, J., Coureul, C., Ramond, D., Pundt, I., Bartlet, L. M., Kerr, J. E., Elokhov, A., Giovanelli, G., Ravegnani, F., Premudan, M., Kostadinov, M., Erle, F., Wagner, T., Pfeilsticker, K., Kenntner, M., Marquand, L. C., Gil, M., Puentedura, O., Arlander, W., Kaastad-Hoiskar, B. A., Tellefsen, C. W., Heese, C. W., Jones, R. L., Aliwell, S. R., and Freshwater, R. A.: Slant column measurements of $\mathrm{O}_{3}$ and $\mathrm{NO}_{2}$ during the NDSC intercomparison of zenith-sky UV-visible spectrometers in June 1996, J. Atmos. Chem., 32, 281-314, 1999.

Sander, S. P., Friedl, R. R., Ravishankara, A. R., et al.: Chemical kinetics and photochemical data for use in atmospheric studies, Evaluation no. 14, JPL Publ., 02-25, 2003.

Sarkissian, A., Pommereau, J. P., and Goutail, F.: Identification of polar stratospheric clouds from the ground by visible spectrometry, Geophys. Res. Lett., 18, 779-782, 1991.

Sarkissian, A., Roscoe, H. K., Fish, D., Van Roozendael, M., Gil, M., Chen, H. B., Wang, P., Pommereau, J. P., and Lenoble, J.: Ozone and NO2 AMF for zenith sky spectrometer: Intercomparison of calculations with different radiative transfert model, Geophys. Res. Lett., 22, 1113-1116, 1995.

Tilmes, S., Müller, R., Grooß, J.-U., Höpfner, M., Toon, G. C., and Russell, J.: Very early chlorine activation and ozone loss in the Arctic winter 2002-2003, Geophys. Res. Lett., 30, 2200, doi:10.1029/2003GL018 792, 2003.

Tilmes, S., Müller, R., Grooß, J.-U., and Russell III, J. M.: Ozone loss and chlorine activation in the Arctic winters 1991-2003 derived with the tracer-tracer correlations, Atmos. Chem. Phys., 4, 2181-2213, 2004,

SRef-ID: 1680-7324/acp/2004-4-2181.

Urban, J., Lautiè, N., Le Flochmoën, E., Murtagh, D., Ricaud, P., De La Noë, J., Dupuy, E., Drouin, A., El Amraoui, L., Eriksson, P., Frisk, U., Jiménez, C., Kyrölä, E., Llewellyn, E. J., Mégie, G., Nordh, L., and Olberg, M.: The northern hemisphere stratospheric vortex during the 2002/03 winter: Subsidence, chlorine activation and ozone loss observed by the Odin Sub-Millimetre Radiometer, Geophys. Res. Lett., 31, 7, L07103 doi:10.1029/2003GL019089, 2004.

Van Roozendael, M., Hermans, C., Kabbadj, Y., Lambert, J.-C., Vandaele, A.-C., Simon, P. C., Carleer, M., Guilmot, J.-M., and Colin, R.: Ground-based measurements of stratospheric $\mathrm{OClO}, \mathrm{NO}_{2}$ and $\mathrm{O}_{3}$ at Harestua, Norway $\left(60^{\circ} \mathrm{N}, 10^{\circ} \mathrm{E}\right)$ during SESAME, Proceedings 12th ESA Symposium on Rocket and Balloon Programmes \& Related Research, Lillehammer, Norway, ESA SP-370, 305-310, 1995.

Vaughan, G., Roscoe, H. K, Bartlett, L. M., O’Connor, F.M., Sarkissian, A., Van Roozendael, M., Lambert, J.-C., Simon, P. 
C., Karlsen, K., Kaastad Hoiskar, B. A., Fish, D. J., Jones, R., Freshwater, L. R., Pommereau, J.-P., Goutail, F., Andersen, S. B., Drew, D. G., Hughes, P. A., Moore, D., Mellqvist, J., Hegels, E., Klupfel, T., Erle, F., Pfeilsticker, K., and Platt, U.: An intercomparison of groundbased UV visible sensors of Ozone and $\mathrm{NO}_{2}$, J. Geophys. Res., 102, 1411-1422, 1997.

Wagner, T., Leue, C., Pfeilsticker, K., and Platt, U.: Monitoring of the stratospheric chlorine activation by Global Ozone Monitoring Experiment (GOME) OClO measurements in the austral and boreal winters 1995 through 1999, J. Geophys. Res., 106(D5), 4971-4986, doi:10.1029/2000JD900458, 2001.
Wagner, T., Wittrock, F., Richter, A., Wenig, M., Burrows, J. P., and Platt, U.: Continuous monitoring of the high and persistent chlorine activation during the Arctic winter 1999/2000 by the GOME instrument on ERS2, J. Geophys. Res., 107(D20), 8267, doi:10/1029/2001JD00466, 2002.

WMO (World Meteorological Organization), Scientific Assessment of Ozone Depletion: 1998, Global Ozone Research and Monitoring Project - Report no. 44, Geneva, 1999.

WMO (World Meteorological Organization), Scientific Assessment of Ozone Depletion: 2002, Global Ozone Research and Monitoring Project - Report no. 47, Geneva, 2003. 